\title{
THE ROLE OF COMMUNITY IN THE DEVELOPMENT OF WAE REBO AS A COMMUNITY-BASED TOURISM DESTINATION IN EAST NUSA TENGGARA
}

\author{
Yefri Yunikson Beeh \\ Sekolah Tinggi Pariwisata Bali Internasional (STPBI) \\ jefriyunikson@gmail.com
}

\begin{abstract}
Wae Rebo is a unique traditional village, known as a famous cone shape house architectures and called in Manggarai language is Mbaru Niang, it has been there since 1920. Mbaru Niang has seven building with the different name, there are Niang Gendang, Niang Gena Mandok, Niang Gena Jekong, Niang Gena Ndorom, Niang Gena Jintam, dan Niang Gena Maro. They were built in a sphere around an altar with the circle shape, called Compang. The people of wae rebo consider Compang as sacred things. Wae Rebo also has other kinds of culture like Penti ceremony and Caci dance. Not only do the have kinds of cultures 2 but they also have rich potentials of nature like mountain range forest, and then any type of bird-like Gagak Flores (Corvus florensis) and Celepuk Flores (Otus alfredi). They are known as the endemic species of Flores Island.

Community-Based Tourism (CBT) is a tourism concept that used in wae rebo tourism development application. CBT concept in the wae rebo tourism application from the beginning like planning, implementation, and the last is controlling doing by society. To protect the culture, people of wae rebo make a community of society organization named Lembaga Pelestari Budaya Wae Rebo and supported by social organization. The motto of that Lembaga Pelestari Budaya Wae Rebo is "Mohe Wae Rebo. Meaning of that motto is Keep Wae Rebo alive.
\end{abstract}


Key Words: Wae Rebo, Mbaru Niang, Culture, Local Wisdom, Community Based Tourism

\section{INTRODUCTION}

\section{Background}

Tourism is anything to do with voluntary and temporary travel activities to enjoy tourism objects and attractions, including entrepreneurial objects and tourist attractions, as well as related businesses in the field (Law of the Republic of Indonesia No. 9 of the Year. 1999 on Tourism). The current development of Tourism greatly affects local people who seek to develop tourism in the region, in the hope to meet the needs and quality of life of the community. The influence of tourism is expected to be able to develop investment, increase employment, and able to lift the image of tourist destinations. The development of tourism is now able to grow to the corners of the region that started as a rural area that only relies on agricultural and plantation crops, the social life of the community, and local wisdom that has existed since the past. Tourism Village Development as an object and tourist attraction will be directly related to tourists who live in a traditional village or close to a traditional village, or just for a stopover visit where the location of this tourist village is usually located in a remote area. Tourists not only witness the traditional culture, but usually participate directly in the activities of local communities. Marpaung (2002). Thus the social role of the community is expected to participate in the development of the tourist village so that there is no gap between the local people and the tourists. One form of participation in the development of tourism is to apply the concept of Community-Based Tourism (CBT). The concept of Community-Based Tourism (CBT) is closely related to sustainable tourism development. Both of them give priority to the benefits of development for society, especially economic, socio-cultural, and environmental benefits (Richards and Hall 2000: 1) in Darma Putra (2015). The influence of Community-Based Tourism (CBT) will be applied in the development of the real Wae Rebo is not an administrative village recognized by the Government. Called 
villages because community communities form a village separated from other communities. Administratively, Wae Rebo belongs to Satar Lenda Village. The development of Wae Rebo as a CBT-based destination, with the excellence of tourist attraction such as Culture Tour, Nature Tour, and Special Interest Tour.

\section{Formulation of the Problem}

Based on the background contained in this proposal the author can draw the formulation of the problem as follows:

1.2.1 What are the components of Tourism Products in Wae Rebo?

1.2.2 How are the Developments of Wae Rebo as a Tourism Destination?

1.2.3 What are the Community Participation in Tourism Development in Wae Rebo?

\section{Research Objectives}

The purpose of this paper is as follows:

1.3.1 To know the components of tourism products in Wae Rebo.

1.3.2 To know the development of Wae Rebo as a tourism destination.

1.3.3 To know the participation of the community in tourism development in Wae Rebo.

\section{Benefits of research}

Benefits of writing this thesis are addressed to Students, Bali International Tourism Institute, Wae Rebo and Local Government of Manggarai Regency.

\subsection{1 for Students}

As an implementation and comparison of the theories that have been studied on the bench with real-life events. It is also used as a pivot for writers to gain knowledge and add insight both theoretically and empirically in scientific work in order to be able to finish thesis well.

\subsection{2 for the International Bali Tourism Institute (STPBI)}

As a means to establish a long-term relationship between the International Bali Tourism Institute and Wae Rebo in Manggarai Regency- East Nusa Tenggara. 


\subsection{3 for Wae Rebo}

As input and evaluation materials for Wae Rebo community to know directly the advantages and disadvantages in managing a region or tourist destinations.

\subsection{4 for the Local Government of Manggarai Regency}

As a reference for the local government of Manggarai Regency, to facilitate community activities in the field of tourism so directly feel the involvement of the government in the management and development of tourism in Wae Rebo.

\section{LITERATURE REVIEW}

\section{Understanding of Tourism}

Tourism is a variety of tourism activities and supported by various facilities and services provided by the community, businessmen, and government. Ismayanti (2010). Tourism is an industry, although tourism increases a variety of industries. Tourism is an activity done by people who travel. Mill (2000). According to Law No.10 (2009) on tourism, what is meant by tourism is a variety of tourism activities and supported by various facilities and services provided by the community, businessmen, government and local government. According to Yoeti (1996: 112) in Suwena and Widyatmaja (2010). Etymologically the word tourism comes from Sanskrit which consists of two words namely pari and wisata. Pari means "many" or "around", while wisata means "to go or" to travel ". On the basis of that, the word Tourism should be interpreted as a trip that is done repeatedly or circling, from one place to another, which in English is called the word "tour", while for the definition of plural, the word "tourism" can be used the word "tourism" or "tourism".

\section{Tourism Development}

Tourism development is a series of efforts to realize the integration in the use of various tourism resources, integrating all forms of aspects outside of tourism-related directly or indirectly to the sustainability of tourism development. Swarbrooke (1996). According to Sunaryo (2013), various lattices of understanding of tourism destinations as well as adapted from many limitations of 
understanding that has been given by experts, such as; Cooper et al (1998) essentially contains the same objective that the tourism development framework should at least include the main components shown in the following illustration:

Figure 2.1. Illustration Chart of Construction of Tourism Destination System

\begin{abstract}
AMENITY
Supporting and supporting tourism facilities include: accommodation, food and beverage, retail, souvenir shop, money exchange facility, travel agency, tourist information center, and other leisure facilities.
\end{abstract}

\section{Objects and Attractiveness}

natural, cultural, or artificial, such as events and so forth.

\section{INSTITUTIONAL}

The existence and role of each element in supporting the implementation of tourism activities.

\section{ACCESSIBILITY}

Support of transportation system which includes: route or transportation line of terminal facility, airport, port and other transportation modes.

\section{Supporting facilities}

Availability of supporting facilities used by tourists, such as banks, telecommunications, post, hospitals, and so forth.

Source: Sunaryo, (2013)

\title{
Community-Based Tourism and Culture
}

Community-based tourism is a type of tourism that promotes community participation in financing, development, management, and ownership. Hausler and Strasdas (2003). According to Garrod (2001: 4) in Pantiyasa (2012), there are two approaches related to the application of the principles of planning in the context of tourism. The first approach that tends to be associated with formal planning strongly emphasizes the potential benefits of ecotourism. The second approach tends to be associated with participatory planning terms that are more concerned with more balanced provisions and arrangements between the building and controlled planning. This approach emphasizes more on sensitivity to the natural environment, in the impact of ecotourism development. One form of participatory 
planning in tourism development is, by applying Community Based Tourism (CBT) as a development approach. Here is a form of community-based tourism development approach:

a. A form of tourism that provides opportunities for local communities to control and engage in the management and development of tourism,

b. Communities that are not directly involved in tourism businesses also benefit,

C. Demand political empowerment and democratization and profit distribution to disadvantaged communities in rural areas.

Culture-based tourism is a type of tourism based on place, tradition, art, ceremonies, and experiences that take pictures of nations/tribes, reflecting the diversity and identity of the community or nation concerned. Cultural tourism can be seen as an opportunity for travelers to experience, understand and appreciate the character of the destination, its wealth and cultural diversity. Cultural tourism provides direct personal contact with local communities and to individuals with special knowledge of a cultural object. Pitana \& Diarta (2009).

\section{Community Participation in Community-Based Tourism Development}

Wae Rebo village is a fully managed destination based on the initiative of the local community. Since the planning, structuring, management, and development are done by the community. In addition to the development and management of Wae Rebo is entirely within the control of local communities, the utilization of financial results from the results of its management was undertaken by local communities. Community participation arises because it is driven by the unique development of the Wae Rebo village attraction, from before it was set until after it was designated as a tourist attraction by the Manggarai Regency Government. The nature of society's participation is the transformational participation of participation that occurs when such participation is seen as a goal, and as a means to an end. A form of Participation includes: First, Participation in making decisions that people participate in community meetings to discuss the arrangement of the attraction of Wae Rebo. Second, Participation in the implementation of the decision is to carry out all the things that have been decided in a joint meeting to manage the tourist attraction Wae Rebo, including participate in maintaining cleanliness, maintain security, organize buildings, and provide 
support facilities. Third, participation in the benefit of the community opened a typical gift shop by Wae Rebo. Fourth, Participation in the evaluation meeting held by Wae Rebo Cultural Conservation Institute conducted once every three months to discuss the problem and how far the arrangement has been done.

\section{Destination Life Cycle}

The level of tourist development in Wae Rebo, when associated with the destination life cycle, is currently in the Involvement stage of increased visitors who encourage locals to offer exclusive facilities to visitors. Contact with local residents remains high and some of them begin to adjust their social patterns to accommodate changes in economic conditions due to the presence of tourists. Promotion of tourism destinations began to be initiated. As shown in the following figure.

Figure 2.2: Tourism Development Cycle in Wae Rebo

Rejuvenation

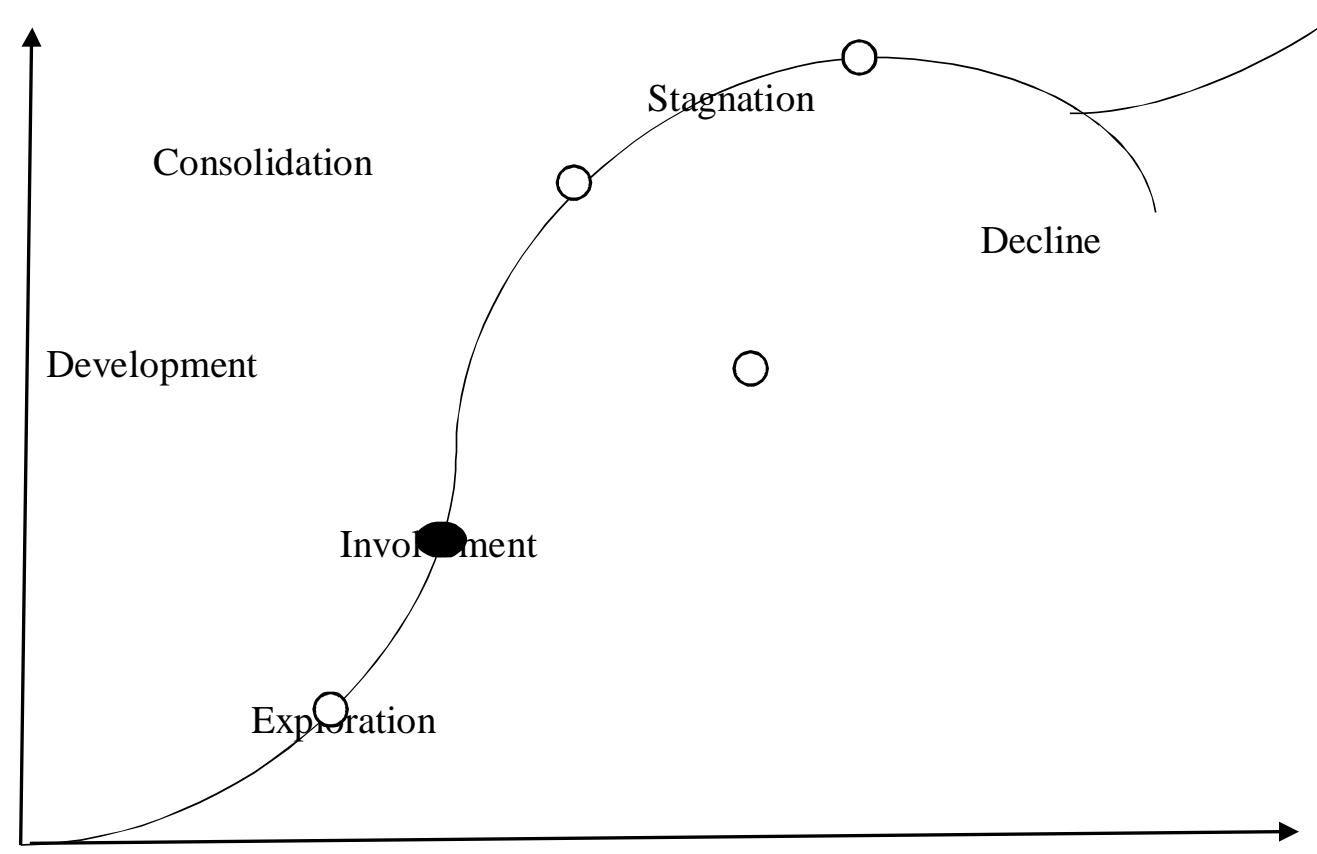

Figure 2.2

Destination area lifecycle Wae Rebo tourism.

Source: (Butler, in Main Rai, 2017) 


\section{RESEARCH METHODS}

\section{Location and time of research}

This research was conducted in Wae Rebo village of Satar Lenda Village, West Satar Mese District - Manggarai Regency - East Nusa Tenggara Province. The reason the author chose Wae Rebo as the object of research because according to the author's view, the area has a uniqueness that has not been encountered by writers in various tourist attractions in Indonesia. Therefore, the writer's great hope is able to produce something good for the research and the object. The study took place from January 2017 to May 2017.

\section{Operational definition}

Community participation in tourism development in Wae Rebo village is the direct involvement of the community that includes planning, management, and control, so that people can feel directly the results and benefits of tourism development in Wae Rebo.

Community Based Tourism (CBT) is a tourism that realizes cultural, social, and environmental sustainability. This form of tourism is managed and owned by the community for the community, in order to help the tourists to raise their awareness and learn about the community and local way of life. According to Nurhidayati (2008) as cited by Gde Satrya (2010) in Hadiwijoyo (2012) defines Community Based Tourism (CBT) as the first, a form of tourism that provides opportunities for local communities to control and engage in tourism management and development. Second, provide benefits to communities that are not directly involved in tourism businesses. Third, demands political empowerment and democratization with the distribution of profits to disadvantaged communities in the countryside. Based on this understanding when associated with the development of tourism in Wae Rebo that the concordance of the concept.

Local wisdom is part of the culture of a society that cannot be separated from the language of society itself. Local wisdom is usually passed down from generation to generation through word-of-mouth. Local wisdom is in folklore, proverbs, songs, and people's games. Local wisdom as a knowledge found by a particular local community through a collection of experiences in trying and integrated with an understanding of the culture and state of nature of a place. In 
Wae Rebo one of the performer is the Pa'u Wae Lu'u ritual. This ritual is led by one of the traditional elders of Wae Rebo, which aims to ask for permission and protection of ancestral spirits against guests visiting and living in Wae Rebo until the guest leaves the village. Not only that, this ritual is also addressed to visitors when it arrives at their place of origin. For the people of Wae Rebo, tourists who come are considered as sisters who are returning home. Before completing this ritual, guests are not allowed to perform any activities including taking photos. Other local wisdom that needs attention is about the use of administrative money for tourists who enter the village of Wae Rebo. There is an impression that administrative costs are always linked to the commercialization of culture, the money is spent, and other questions that are always associated with corruption. But the administrative money in Wae Rebo is already set according to local wisdom. This money management is entrusted to Wae Rebo Cultural Conservation Institute. Administrative money earned by tourists is used for food and cooking purposes made by mothers, maintenance of village infrastructure, fuel generator sets and water sources.

Tourism Destination is a geographical area located within one or more administrative areas within which there are tourist attractions, public facilities, tourism facilities, accessibility, and interconnected communities and complete the realization of tourism. (Tourism Act No. 10 of 2009). The presence of Wae Rebo as a tourist destination is in line with the tourism law number. 10 the year 2009 is located within the administrative area of Manggarai Regency, Satar Mese West District-Desa Satar Lenda. As for Wae Rebo has facilities such as toilet, bathroom, health center, reading park, electric current. Tourist facilities such as guest houses, tourist information, and souvenir shops. Accessibility to Wae Rebo is adequate and access to destinations is good for tourism access.

Indigenous People Wae Rebo is now an indigenous community that has been living for many years and has had nineteen generations in the life cycle of the village since Empo Maro. The people who live in the village and live in Mbaru Niang is only 600 people while the rest of the people live in Kampung Kombo, which is approximately eight kilometers from Wae Rebo on the slope of the mountain and has easier access. Although the distance from Wae Rebo to 
Kombo village is very remote the people who live in both villages are indigenous people.

\section{Types and Data Sources}

Based on the type of data used in this study are as follows:

a. Qualitative Data

Qualitative data is data in the form of words, sentences, gestures, facial expressions, charts, pictures and photos. Sugiyono (2014). In this study qualitative data is data information that is described in detail about the general picture of wae rebo. This data was obtained by in-depth interviews and Focus Group Discussion results with informants (Wae Rebo customary chairman, Wae Rebo Cultural Conservation Institute, Local Community of Wae Rebo, and observations).

b. Quantitative Data

Quantitative Data is all information collected from a field that is expressed in numerical or incentive forms. Pantiyasa (2013). Quantitative data in this paper are data in the form of numbers - numbers include the number of residents Wae Rebo, education level data, livelihood data, and data on tourist visits in Wae Rebo.

Based on Source Data used in this research consists of two namely:

a. Primary Data

Primary data is data collected by researchers directly from the source recorded, observed then processed to answer problems in research. Pantiyasa (2013). This data was obtained by in-depth interviews and Focus Group Discussion results with informants (Wae Rebo customary chairman, Wae Rebo Cultural Conservation Institute, Local Community Wae Rebo, and observations.

b. Secondary Data

Secondary data is data obtained by researchers in the form of data that has been so not from the results of collecting and processing themselves. Pantiyasa (2013). Sources of secondary data from this research are in the form of literature or documents, research journals, websites and various reports relating to the problems studied and other literature that can support this research. 


\section{Data Collection Technique}
a. In-depth Interview
b. Observation
c. Documentation
d. Focus Group Discussion

\section{Data Analysis Technique}

The technique in analyzing the data, the writer using data analysis techniques proposed by Miles and Huberman (1984) in Sugiyono (2014) suggests that the activity in analyzing the qualitative data is done interactively and lasted continuously until complete, so the data is saturated. Activities in analyzing the data include: First, Data Reduction Reduce data means summarize choosing the things that matter, focus on things - things that are important, sought the theme and pattern. Data reduction can be assisted with electronic equipment such as mini computers, by providing codes on certain aspects. Second, Data Presentation (Display Data) after doing data reduction can be done by displaying data. In the presentation of qualitative data can dispensed in the form of brief descriptions, relationships between categories, flowcharts and the like. According to Miles and Huberman, (1984) in Sugiyono (2014) states that the most commonly used to present data in qualitative research is with narrative text. Third, the Conclusion Drawing / Verification technique of this analysis is the conclusion and verification. Conclusions in qualitative research are new findings that have not previously existed. The findings obtained can be a description or description of an object that was previously still unknown so that after the investigation is expected to become famous.

\section{RESEARCH RESULT AND DISCUSSION}

\section{Profile of Wae Rebo}

Wae Rebo is a traditional village located in Manggarai Regency, West Satar Mese District, Satar Lenda Village - East Nusa Tenggara Province. Wae Rebo is located at an altitude of 1,117 above sea level above Flores highland forest, the temperature of the village area reaches 21 degrees Celsius at night, 
while in the morning the sun lights out at nine o'clock when the weather is sunny while the cloudy sun rises at 11 noon. The total population in Wae Rebo is made up of 44 heads of households and 600 people in total. Community work, in general, is a farmer, consisting of coffee farmers, rice farmers, and gardening. Most of the people of Wae Rebo are an elementary school but as time goes by several children from Wae Rebo village wander to education in cities such as Ruteng, Labuan Bajo and even those who study in Bali. The main income of the people of Wae Rebo is in addition to the tourism sector, namely by selling agricultural crops and plantations, among others, by selling coffee beans, cinnamon, candlenut, ginger and turmeric in traditional markets held every Monday in Dintor. Typical food in the form of rice, corn, and sweet potato cassava which is usually consumed with black coffee is traditional food.

\section{Components of Tourism Products in Wae Rebo}

The components of tourism products Wae Rebo which offer include:

\subsubsection{Attractions}

a. Nature Tourism Attractions

Beautiful natural scenery is served in the mountains along the way to Wae Rebo and the variety of biodiversity encountered varies. Based on a survey conducted by Indecon in 2013, that there are 42 species of trees that live within the protected forest. The tree species found are Natu tree (Planchonella firma), Ketang (Planchonella obovata), Maras (Dysoxylum sp), Worok (Dysoxylum nutans), Moak (Dacrycarpus imbricatus), Pinis (Adebandra javanica), Pinis (Podocarpus amarus), Rukus (Adinandra javanica), Kenti (Leptospermum flavescens) Rentigi (Vaccinium timorensis) and Mpuing (Decaspermum fruticosum). Based on the survey, Indecon successfully recorded 38 species of birds found in the mountain forests. Two of them are Flores endemic birds namely Gagak Flores (Corvus florensis) and Celepuk Flores (Otus alfredi). In addition to birds there are several other wildlife forest dwellers (Sucelebensis), long-tailed monkeys or Kode (Macaca fascicularis), squirrels (Callosciurus notatus), civet (Paradoxurus Hermaphroditus), and hedgehog (Hystrix javanica). 


\section{b. Cultural Tourism Attractions}

Wae Rebo is one of the traditional villages that still maintain the authenticity of the village, the authenticity of building architecture, community life and customs to date. At the time of visiting Wae Rebo tourists will witness firsthand some cultural attractions that exist there but there are some cultural attractions that cannot be directly witnessed because of the time when the tour is not right. Travel time is not right because some of the cultural attractions Wae Rebo will be staged during the event a great event in certain months. Therefore, in the writing of this scientific paper the author describes the cultural attractions contained in Wae Rebo.

1) Building Architecture of Wae Rebo

Mbaru Niang is the uniqueness behind the privileges of Wae Rebo village. Mbaru Niang is a traditional house and has a distinctive architecture abandoned by the ancestors of the Wae Rebo community. Mbaru means house while Niang means high and round. Mbaru Niang is a house built in a different architecture with the building of the house in general because of the cone and towering upward. Wilhelmus Rupun as vice chairman of LPBW, revealed that this form of Mbaru Niang has a very big meaning because it is a symbol of protection and unity of the people of Wae Rebo. While the floor of Niang is rounded that symbolizes harmony and justice for all the people who live in it. Mbaru Niang has been preserved by the Wae Rebo community from generation to generation since abandoned by an ancestor that has lasted for 19 generations. Mbaru Niang Wae Rebo consists of seven buildings that stand upright since its founding in 1920 until today. The building only consists of seven niang only, because it is said the story of the ancestors founded the seven Niang in honor of the seven directions of the mountain peaks that surround the village of Wae Rebo is also believed to protect the prosperity and peacefulness in the village. Among the seven buildings there is a circular altar in the middle of the group Mbaru Niang Wae Rebo people call it Compang. Compang is the center of the seven Niangs believed by the people of Wae Rebo as the place that has the most sacred value, because it serves as a place to perform ritual worship and offerings to God and the ancestors. 
The seven Niang buildings have different custom names, among others; Niang Gendang, Niang Gena Mandok, Niang Gena Jekong, Niang Gena Ndorom, Niang Gena Pirung, Niang Gena Jintam, Niang Gena Maro. Of the seven Niang Niang Gendang has a size larger than six Niang Gena, while the six other Gena Niang have the same size. Rupun (2017). Mbaru Niang has five levels with their respective custom names and seven important sections that have different meanings as well. Here is an explanation of the names and functions of the five levels of Mbaru Niang. Hekang Kode (level 5): Serves as a storage space offerings for ancestors in the form of woven bamboo or cage; Lempa Rae (level 4): Serves as a food storage space; Lentar (level 3): Serves as a storage space for seeds - livestock and garden seeds; Lobo (level 2): Serves as a storage room for other goods; Tenda (Level 1): Serves as a space of human activity / occupants. Inside is a gathering room, furnace and dining room and bedroom for 6 - 8 family heads. The explanation of the names and meanings of the seven important parts of Mbaru Niang include: Ngando: Serves as a roof cover as a whole is also installed ben dera during the celebration of 17 August; Bongkok: Serves as a central building that has a high sacred value, as well as seat of adat chairman while performing waelu'u; Buku Bambu: Serves as a roof frame that also serves as a roof buffer; Wehang: Serves to close to protect the occupants from rain or sun; Pintu: Serves as a way out or entering a house; Pondasi: Serves as a support for Mbaru Niang building. Activities undertaken by the community while inside Mbaru Niang's building are housed in the very first level (tenda), the size of the tenda inside the Niang Gendang is larger than the sixth Niang Gena which is 14 meters in size while the sixth Niang Gena is 11 meters in size. The size difference is caused by the number of residents in Niang Gendang more than in the six Niang Gena which is eight family head while the sixth in Niang Gena is six family head. Inside the tent was divided into two parts namely Motang and Lutur which have different functions. Motang as a private zone where there is a furnace for cooking and family meals, as well as bedrooms. The order of the bedrooms is arranged according to the order of birth of each head of the family. The concept of the circle is used to organize the seven Mbaru Niang where Compang as the most sacred part as well as the concept that is in the room that is bent as the center point 
is also neutralized. Therefore, the customary chair is always sitting in front of the pole bongkok because he was sacred by the people of Wae Rebo.

\section{2) Penti Ceremony}

Penti is one of the traditional ceremonies Wae Rebo community, this ceremony held every month Beko (November) which is believed by the people of Wae Rebo as a new moon in the calculation system of the month. Penti custom ceremony held as a form of gratitude to the Creator. Penti celebration is also held as a celebration of the New Year and thanksgiving for the success given by the Creator for a whole year. Penti ceremony was done in the hope that the community Wae Rebo obtain the same success in the year to come. Penti ceremony is considered as a traditional ceremony to prepare new plant seeds or in the local language Wuat Wini to be planted in the garden, with the implementation of Penti community hope that the seeds that have been planted are blessed by the Creator so that the results obtained at harvest is a good result. The Penti custom ritual is performed for one day with several ceremonial stages, ie blessing of springs, village safety, and evil spirits. People are called to gather at Rumah Gendang then go to the place of ritual accompanied by singing Sanda. Sanda singing is only performed during the Penti ceremony. Then proceed with the performance of Caci dance.

\section{3) Caci Dance}

Caci is a traditional dance of Manggarai performed in several traditional ceremonies as well as major events such as Penti Ceremony, Independence Day celebration of Republic of Indonesia, wedding day, and reception of State guests. Caci dance is performed by two men to show their strengths. One of the two men whips the opponent and then responds with a repeat and whips against the opponent in turn, lasting for a few minutes to complete. The Caci dance is identical to the male power in Manggarai because it deals with courage, masculinity and fascination for women. The main performer of Caci dance is male but not all can do it because Caci dance is performed only by brave men, strong and clever in performing dance movement, and singing regional song, because at the time of this dance will be accompanied by drum music, gong, as well as regional singing such as Lando and Mbaku. Caci dance based on his philosophy is 
as follows; Caci is a communication between God and Man. Ca means one and Ci means test, therefore the dance is only made up of two people that has the meaning that God test the players one on one, in order to know the two dancers are guilty or not. One of those tests is a whip symbolizing flashes of lightning. Lightning represents the judgment of God but the lightning also symbolizes the relationship of heaven and earth. Caci is the symbol of God, the unity of Mother Earth with the Father of Heaven. While the existing shield on the right hand is the symbol of Rahim and Mother Earth, and the wicker stick in the left hand is symbolizing the sky. Wailing whips connecting the motherland and the emblem of the sky. The scars of Caci dance became a pride for the dancers because it is considered as a symbol of masculinity.

As for some of the attributes used when performing Caci dances include: 1) White Pants and Songke Cloth (puth pants used then wrapped with songke cloth symbolize innocence, generosity, sincerity, courtesy and compliance of Manggarai people); 2) Ndeki (an attribute that is shaped like a ponytail attached to the waist part of a dancer made of rattan and white goat hair symbolizes virility and strength); 3) The bells (mounted on the back of the waist that later bergemirincing following dance moves that demonstrate by dancers); 4) The Panggal Mask (used in the head symbolizes the strength and charisma of the Manggarai people; 5) Larik (a whip used as a weapon, made of dried buffalo leather and fitted with woven rattan at the end); 6) Nggiling (is a round shield made of dried buffalo leather, its function is to block an opponent attack while performing a Caci dance); 7) Agang or Tereng (a bow made of small bamboo or rattan that serves as a tool to fend off the opponent's attack.

4) The Sacred of Weasel

Weasel is an animal that is highly respected by the people of Wae Rebo. It is said that when he lived in the village of Popo, Empo Maro and his relatives experienced an event that later made the people of Wae Rebo not dare to kill or eat the meat. The story begins with a conflict that occurs when there is a mother who is pregnant but the mother is difficult to give birth when the pregnancy has passed a normal pregnancy, then Empo Maro decided that he should help by splitting the mother's stomach using a knife with the aim that the children are born 
safely. Empo Maro's decision to save the child but the mother's life cannot be saved. A few years later, the news of the mother's death was due to the fact that Empo Maro's labor was wrong to cause the mother to die. The mother's family was so angry that she planned to attack the Empo Maro, but there was a weasel coming to save Empo Maro. The weasel tells the intentions of the mother's family who will attack the Empo Maro, so the weasel also advises to leave the village immediately, Empo Maro responds well so that he survived the attack. Therefore the story of the weasel that saved the Empo Maro family was inherited until now and became a very sacred animal in the village of Wae Rebo.

\section{c. Special Interest Tour Attractions}

\section{1) Agro Tourism}

In addition to nature and culture developed as a tourist attraction in Wae Rebo is an alternative tourism one of agro-tourism. Wae Rebo agro-tourism is offering tourists to feel different things that tourists are invited to surround the coffee plantation while introducing some types of coffee that existed in the plantation. Wae Rebo agro-tourism is still very new because it was launched in 2013, to offer different things that introduce the type of coffee Wae Rebo to tourists. Some of the original types of Wae Rebo coffee are Arabica, Robusta, and Columbia coffee are excellent coffee runs without the use of medicines such as pesticide, but the coffee trees are allowed to grow according to the actual cultivation cycle so as to produce a typical coffee bean with the original aroma. The community will offer tourists the right to get involved in picking coffee beans a few meters away from the village. Katup, (2017).

2) Hiking Tours

The presence of Wae Rebo village above the altitude of $1.117 \mathrm{dpl}$ is an access that is desired by tourists lovers of hiking, therefore when a trip to the unique village tourists is encouraged to keep the physical condition to stay healthy so as not to interfere on the way. Hiking is done for 4 hours but this time certainly does not mean if the selected tourist object for the trip in accordance with the hobby of tourists. The trail is a little steep but the scenery during hiking activities will eliminate the fatigue. 


\subsubsection{Accessibility}

Access to reach Wae Rebo there are two routes, among others, through Ruteng and Labuan Bajo. Access through Labuan Bajo takes four hours to arrive at Waelomba which is the first post. While access through Ruteng line takes 5 hours to arrive at Waelomba by motorcycle. If passing Labuan Bajo road better access road because the path traversed tends to be straight and slightly perforated while access through Ruteng path through which winding and many points of damage. However, if you choose access through Ruteng, when tourists arrive at Labuan Bajo International Airport must spend four hours travel by travel after arriving in Ruteng then tourists need three hours to arrive at Waelomba. To arrive at Waelomba tourists will use the same transportation through both channels, among others; Cars, Motorcycles, or wood trucks or in the local language known as Cole Oto which is used specifically for the transports of Waelomba destinations.

When traveling to Wae Rebo from Labuan Bajo, tourists will pass several famous attractions such as Todo and Spider Rice Field Cancar. Spider Rice Field Cancar is a rice field belonging to the Manggarai community that has a form similar to a spider's web, but based on the Manggarai community story that the shape of the rice field has the same story as the Mbaru Niang framework in Wae Rebo. If tourists choose to pass through Ruteng then it will pass some interesting objects such as; Liang Bua, Pantai and Pulau Mules.

\subsubsection{Amenities}

The facilities and infrastructure available at Wae Rebo are currently very adequate, consisting of two guest houses available. At the time of increasing number of tourists visit to Wae Rebo and want to settle but availability of lodging facilities have not existed so affect the development of tourists. Then in 2009 the community agreed together to use one of the seven Mbaru Niang to serve as guest house that is Niang Gena Maro because his position is considered suitable for that and not too close to Niang Gendang. Then in 2013 as the development of tourist visits to the community Wae Rebo agreed together to build a new guest house on the back of Niang Gena Maro. The addition of a new guest house with an architecture that resembles seven other Niangs to provide comfort for tourists. The 
facilities available inside the guest house are beds, consisting of a stretch of floor mats, pillows and a thick blanket. As for some other supporting facilities such as tourist information center (tourist information center) is provided in the guest house. To get by (by souvenirs) from Wae Rebo, there is a small outlet that specifically provides the necessities, but when visiting at the time of custom activity usually souvenirs on display by hanging. Types of souvenirs provided include; woven fabrics such as sarongs, songke, shawls and miniature Mbaru Niang and typical coffee Wae Rebo which is sold at an affordable price.

\subsubsection{Ancillaries}

Other supporting facilities available in Wae Rebo is the availability of healthcare facilities such as puskesmas served by a medical officer from Wae Rebo since 2013. The educational facilities such as a reading park that provides a variety of books both school textbooks and general knowledge in donated by several Non-Governmental Organizations (NGOs) as well as by tourists. The power source in Wae Rebo since 2005 uses generators and in 2014 the public receives additional donations from Solar Cell, by pairing solar panels. Source of water obtained free of charge because it comes from the mountains so it helps the people of Wae Rebo in fulfilling daily needs such as bathing, cooking, and other needs. In 2012 the people get help from rural self-reliant PNPM that donates some water tanks to make it easier for people to get clean water.

\subsubsection{Institutions}

The people of Wae Rebo have formed an institution or community organization called Lembaga Perlestari Budaya Wae Rebo (LPBW), which aims to regulate the development of tourism and community life in Wae Rebo. The organization is formed based on the level of customs and competencies possessed by members of the community.

\section{The Development of Wae Rebo As a Tourism Destination}

The development of tourism in Wae Rebo continues to experience a positive increase, therefore the expectation from the public that the current increase of tourists will continue to grow up. 
Table 4.1 Tourist Visiting Data In Wae Rebo Period Year 2011 - 2015

\begin{tabular}{|c|c|c|c|c|}
\hline \multicolumn{5}{|c|}{ TOURIST VISITING DATA IN WAE REBO PERIOD YEAR 2011 - } \\
2015 & \multicolumn{5}{|c|}{} \\
\hline NO & YEAR & $\begin{array}{c}\text { INTERNATIONAL } \\
\text { TOURIST }\end{array}$ & $\begin{array}{c}\text { DOMESTIC } \\
\text { TOURIST }\end{array}$ & TOTAL \\
\hline 1 & 2011 & 345 & 48 & 393 \\
\hline 2 & 2012 & 383 & 300 & 683 \\
\hline 3 & 2013 & 424 & 617 & 1.041 \\
\hline 4 & 2014 & 1.158 & 1.398 & 2.556 \\
\hline 5 & 2015 & 1.249 & 2.197 & 8.119 \\
\hline & & TOTAL & & \\
\hline
\end{tabular}

Source: (Tourism and Culture Office of Manggarai Regency).

The current development of Wae Rebo tourism, based on observations in research objects and analysis of the results, Wae Rebo tourism when associated with the Destination life scale by Butler in Pitana and Diarta (2009) is at the Involvement point. The public's success in developing tourism is proof that Wae Rebo's tourism strength is the participation of society as a whole. The form of Wae Rebo community participation will be described in detail as follows: First, community participation is jointly involved in discussing and making decisions on Wae Rebo tourism plan and development in the future in a meeting facilitated by Lembaga Pelestari Budaya (LPBW). Second, community participation in accountability of tourism management plans in Wae Rebo. The participation is to maintain security, to maintain cleanliness, to keep ancestral objects, to preserve local wisdom and more especially to mothers participating in processing and preparing food for tourists. Third, the community participation in obtaining benefits is by selling the loom, selling some typical souvenirs from Wae Rebo. 
Fourth, community participation in evaluation meetings held by LPBW that takes place every month to discuss the results achieved, and the end of the year discussing finance and all activities for one year. Fifth, full community participation in attending all meetings organized by LPBW. The benefit that Wae Rebo community gets from participating directly in tourism development is that people do not have to go far to look for work but will work in their own country. The community directly maintains and preserve the cultural and local wisdom possessed. While other income earned is from the results of the division of lodging costs and souvenirs.

With the tourism activity is very helpful for our economy who only work as a farmer ... income from agricultural crops hanging the harvest season if the results are good we are happy if the bad results we live hard ... now there are tourism activities now even if the income depends on the number of people who visit here but very help us 1000 percent haha ... income from tourism yes it from lodging costs 325.000 rupiahs every one 25.000 rupiahs given to the tourism office while the rest of it for the whole community here. (Interview with Wilhelmus Rupun as vice chairman of LPBW, dated 17 March 2017).

Based on the above statement it can be known how much income earned in the community Wae Rebo from the field of tourism.

\section{Development of Community-Based Tourism (CBT) Concept in Wae Rebo}

Five aspects that become important supporters in applying the concept of Community Based Tourism are described in Matutano (2016). The similarities in social aspects include the increasing quality of people's lives, among others, increasing education with schools outside Wae Rebo, increasing community pride such as Wae Rebo village when better known for the influence of tourism than before the existence of tourism activities, equity in everything such as housewives in Wae Rebo is directly involved in tourism activities including being a member of institutional management, directly involved in planning, management, decision-making and other tourism activities. The similarity in the economic aspect is the availability of funds derived from tourism activities for the use of tourism development in Wae Rebo, thus increasing employment for local communities one of them being a tour guide. The similarity in the cultural aspect is to encourage the people of Wae Rebo to be more respectful of cultural differences therefore people have done that by opening themselves and accepting 
the whole culture that exists in the world, the society has helped tourists in terms of culture that is by sharing knowledge about the culture of Wae Rebo so that tourists are interested to learn it, tourism development is always attached to local culture in Wae Rebo like a polite way of speaking to tourists, always using custom clothing which is a daily-used clothing. The similarity in the political aspect of public participation has been increasing since the tourism activity to date, because the activities undertaken in Wae Rebo all communities are required to be directly involved based on the activities that have been accounted for, the increase of community in Wae Rebo is wider because of the cooperation with some tourism NGOs. The right to guarantee the management of natural resources based on the Regulation of Manggarai Regent, by issuing a Decree that Wae Rebo is designated as Manggarai Regency Heritage Site, and Wae Rebo is under the supervision of the Ministry of Forestry. Equal environmental aspects, studying the Carrying Capacity Area, garbage disposal is to provide a trash can.

\section{CONCLUSIONS AND SUGGESTIONS}

\section{Conclusions}

Based on the results and discussions that have been described then it can be concluded as follows.

1. Viewed from the aspect of tourism product components, the development of Wae Rebo as a destination is supported by the existence of several tourism potentials such as: 1) Tourist Attraction: has beautiful nature, riches of biodiversity, culture, and strong local wisdom, possesses unique architecture, agro tours, and hiking. 2) Accessibility of the road is adequate for a destination area but slightly winding and passing through mountain areas. 3) available facilities, among others; Adequate accommodation is complemented by typical Wae Rebo souvenirs and tourist information centers. Other supporting facilities available are clean water, public health centers, reading houses, showers and toilets for travelers, power sources and places of worship. 4) The existing institute is a community organization formed based on mutual agreement of Cultural Conservation Institute Wae Rebo (LPBW) with the motto in local language "Mohe Wae Rebo". 
2. Community participation in tourism development in Wae Rebo is from the beginning. The form of community participation is composed of five forms: Firstly, community participation is jointly involved in discussing and taking decisions for future plans and tourism development of Wae Rebo in a meeting facilitated by Lembaga Pelestari Budaya (LPBW). Second, community participation in accountability of tourism management plan in Wae Rebo. The participation is to maintain security, to maintain cleanliness, to keep ancestral objects, to preserve local wisdom and more especially to mothers participating in processing and preparing food for tourists. Third, the community participation in obtaining benefits that are by selling the loom, sell some typical souvenirs. Fourth, community participation in evaluation meetings held by LPBW that takes place every month to discuss the results achieved, and the end of the year discussing finance and all activities for one year. Fifth, full community participation in attending all meetings organized by LPBW.

3. The development of tourism in Wae Rebo is to improve the quality of attraction based on the components of tourism products, improve cooperation with tourism industry players, improve the quality of human resources, and promote promotion through internet and television media on an ongoing basis.

\section{Suggestions}

In this paper, the authors provide advice to:

1. To the Local Community

a) Always active in receiving tourists.

b) To be involved directly in the traditional weaving process.

c) To support the innovation of products created by tourism actors in Wae Rebo such as participating in teaching traditional weaving with tourists.

d) Keep the preservation of nature, cleanliness of the environment and security and comfort of tourists during their stay in Wae Rebo.

e) Maintain local wisdom and keep sacred objects and the sacredness of the village. 


\section{Tourism Actors}

a) Creating innovative new breakthroughs to attract tourists such as involving tourists in community activities directly such as traditional weaving

b) Creating new innovations like selling Wae Rebo coffee as a souvenir to take home.

c) Increase promotion through online media and supporting media such as television, newspapers, and brochures.

d) Enhance services to make tourists feel safe and comfortable.

e) Improving the cleanliness of accommodation facilities and supporting infrastructures such as toilets and showers, clean water supplies, and foodstuffs.

3. Local Government of Manggarai Regency

a) Increasing people's human resources by conducting training on tourism.

b) Providing socialization and information related to tourism policies and developments in Wae Rebo.

c) Cooperate with travel agencies outside Manggarai regency to participate in promoting and selling Wae Rebo tourism.

d) Enhance promotions through online media and supporting media such as television, international newspapers or promoting directly to the country of origin of tourists so that foreign tourists visit increasing.

\section{REFERENCES}

Hevner, Alan dan Chatterjee, Samir. 2010. Design Research in Information Systems. New York: Springer.

Katup, Yosef. 2013. Menjaga Warisan Leluhur di Wae Rebo. Artikel Travel Kompas.com

http://travel.kompas.com/read/2013/10/28/1117022/Yosef.Katup.Menjag

a.Warisan.Leluhur.di.Wae.Rebo diakses 21 Februari 2017. 17.00.pm

Marpaung, Happy. 2002. Pengetahuan Kepariwisataan. Bandung: Alfabeta. 
Matutano, J.C. 2012. The Effects of Community Based Tourism on Socio-Cultural Values. United Kingdom. Akademikerverlag.

Merriam, S.B dan Tisdell, Elizabeth. 2016. Qualitative Research A Guide to Design and Implementation. San Fransisco: Jossey -Bass.

Mill, R. C. 2000. Tourism The International Business. Jakarta: Rajawali Pers.

Pantiyasa, I Wayan dan Kornelius, I Made. 2011. Pengembangan Pariwisata Berbasis Masyarakat (Community Based Tourism) Menuju Pariwisata Berkelanjutan dan Pemberdayaan Masyarakat. Jurnal Kepariwisataan.

Pitana, I. Gde dan Diarta, I.K.S. 2009. Pengantar Ilmu Pariwisata. Yogyakarta: ANDI.

Prasiasa, D.P.O. 2013. Destinasi Pariwisata Berbasis Masyarakat. Jakarta: Salemba Humanika.

Putra, I. N.D. 2015. Pariwisata Masyarakat Model Bali. Bali: UNUD \& Buku Arti.

Sugiyono, 2014. Metode Penelitian Manajemen. Bandung: Alphabeta.

Suhandi, A.S., Simatupang, W., Sungkar, R. dan Farizky. 2016. WAEREBO. Jakarta: Yayasan Ekowisata Indonesia (INDECON).

Tingkat, I Nyoman dan Putra, I.N.D. 2015. Pengembangan Pariwisata Berbasis Masyarakat Adat di pantai Pandawa. Jurnal Kepariwisataan.

Utama, I.G.B.R. 2016. Agrowisata Sebagai Pariwisata Alternatif Indonesia. Yogyakarta: Deepublish.

Utama, I.G.B.R. 2017. Pemasaran Pariwisata. Yogyakarta: ANDI.

Wardiyanta. Metode Penelitian Pariwisata. Yogyakarta: ANDI.

Yuliana, F. 2015. Partisipasi Masyarakat dalam Pengelolaan Daya Tarik Wisata Ceking. Jurnal Kepariwisataan. 